\title{
Sesgo de inmortalidad en estudios observacionales
}

\author{
Diego Pérez de Arenaza \\ Cardiólogo. Medico de Staff, Hospital Italiano de Buenos Aires. Ciudad Autónoma de Buenos Aires, Argentina. \\ Coordinador: Rodolfo Pizarro \\ Máster en Efectividad Clínica. Jefe de Cardiología Hospital Italiano. Ciudad Autónoma de Buenos Aires, Argentina.
}

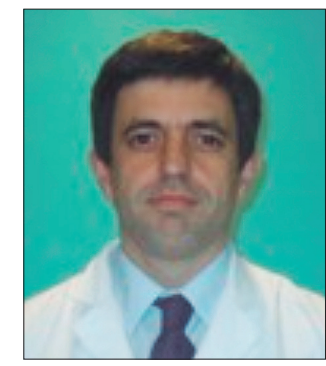

Diego Pérez de Arenaza

Acta Gastroenterol Latinoam 2021;51(2):125-127

Recibido: 13/05/2021 / Aceptado: 14/05/2021 / Publicado online: 21/06/2021 / https://doi.org/10.52787/ajuj5684

Los sesgos, en el diseño de los estudios observacionales, son una de las principales fuentes de asociación espuria, en adición a los errores del azar o los confundidores. El sesgo de inmortalidad es un tipo de sesgo que, en muchas ocasiones, ocurre de manera inadvertida para los investigadores. Este sesgo consiste en que existe un período, en la observación de los sujetos, en el que el evento o punto final del estudio no puede ocurrir. Esto es particularmente importante cuando comparamos la incidencia de un evento entre dos grupos: uno con una variable de exposición y otro sin la variable de exposición. El sesgo de inmortalidad ocurre, frecuentemente, cuando, en el grupo expuesto, existe un período de seguimiento entre el ingreso al estudio y la determinación de la variable de exposición, período en el que el evento o punto final, por definición, no ocurre. Esto da como resultado una incidencia menor del evento en el grupo expuesto en comparación con el grupo no expuesto (Figura 1). Esta diferencia de incidencia no es real, sino que está sesgada por el diseño del estudio, que ocasiona el sesgo de inmortalidad donde los sujetos están protegidos, por un tiempo, de de-

Correspondencia: Diego Pérez de Arenaza

Correo electrónico: diego.perezdearenaza@hospitalitaliano.org.ar sarrollar el evento en el grupo expuesto. Esta situación se da cuando el ingreso a la cohorte ocurre antes de la determinación de la variable de exposición. De este modo, llamamos sesgo de inmortalidad, cuando existe un periodo de tiempo entre el ingreso a la cohorte y la determinación de la variable de exposición en el que no puede ocurrir el evento por definición.

Sharif SZ describe claramente, a partir de un artículo de Hemmelgarn y colaboradores, el sesgo de inmortalidad. ${ }^{1,2}$ En el artículo mencionado, los autores informan una reducción del 50\% en el riesgo de mortalidad por todas las causas, para los pacientes que tenían enfermedad renal crónica y asistían a clínicas de atención multidisciplinaria en comparación con aquellos que habían recibido la atención habitual. ${ }^{2}$ Las curvas de mortalidad divergen rápidamente entre el grupo que asistía a clínicas de atención multidisciplinaria comparado con el tratamiento estándar. No existe plausibilidad biológica en el hecho de que asistir a una clínica de atención multidisciplinaria resulte en una reducción inmediata y tan marcada de la mortalidad. La reducción en la mortalidad podría ocurrir con el tiempo (meses o años), en caso de que se acompañe a los pacientes evaluados en la clínica de atención multidisciplinaria de un tratamiento más completo, con intervenciones de eficacia probada y basadas en la evidencia y/o asociadas con una mayor adherencia a las intervenciones realizadas. La reducción inmediata observada solo se explica por el sesgo de inmortalidad. El estudio de Hemmelgarn consistió en una cohorte retrospectiva de 187 pacientes clínicos, expuestos a una clínica de atención multidisciplinaria, que se emparejaron con 187 pacientes de control clínico que no eran clínica de atención multidisciplinaria (atención estándar) para examinar la asociación entre clínica 
Figura 1. Gráfico de estudio de cohorte, en el que se grafican el grupo expuesto y el no expuesto. El periodo entre el ingreso al estudio y la determinación de la variable de exposición corresponde al periodo de inmortalidad (no puede ocurrir el evento).

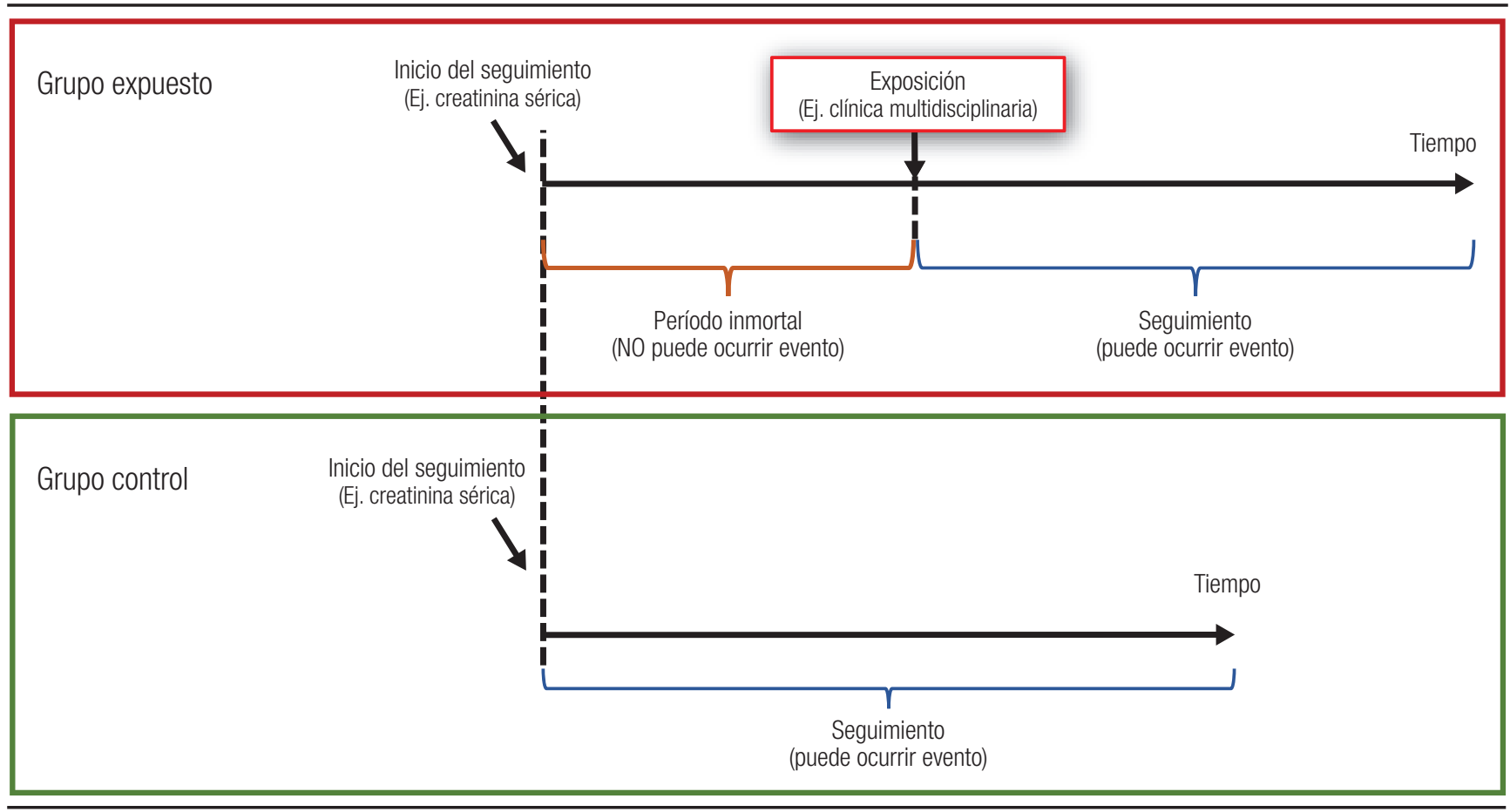

de atención multidisciplinaria y supervivencia. Los sujetos de control se eligieron sobre la base de la propensión a emparejar, por lo que los individuos del grupo de control tenían una probabilidad similar de ser remitidos a una clínica de atención multidisciplinaria que los del grupo de clínicas de clínica de atención multidisciplinaria. Todos los pacientes debían tener una prueba de creatinina sérica para pacientes ambulatorios realizada entre el $1^{\circ}$ de julio y el 31 de diciembre de 2001. Los pacientes, en el grupo de la clínica de atención multidisciplinaria, también debían haber asistido a una clínica de atención multidisciplinaria entre el $1^{\circ}$ de julio de 2001 y el 31 de diciembre de 2002. Se usó un análisis de supervivencia de Cox, entre el grupo clínica de atención multidisciplinaria y el grupo estándar. El tiempo de supervivencia se midió a partir de la fecha de la prueba de creatinina sérica de cada paciente. En otras palabras, la fecha de la creatinina sérica de cada paciente representaba la fecha en que ingresaron a la cohorte, o el tiempo 0. Se siguió a los pacientes hasta el final de la evaluación (31 de diciembre de 2004) o hasta la muerte, lo que ocurriera primero. Se ilustró una diferencia en la supervivencia entre los dos grupos, mediante las curvas de supervivencia de Kaplan-Meier (Figura 2). En este análisis, la censura se produjo solo al final de la evaluación; por lo tanto, las curvas representan esencialmente la proporción de pacientes que todavía estaban vivos, en cada momento, durante el seguimiento. Las curvas divergen de forma inmediata, lo que remarca el sesgo de inmortalidad.
Después del año y medio, las dos curvas tienen una pendiente similar. Gran parte del efecto beneficioso temprano observado puede deberse al sesgo de inmortalidad.

Figura 2. Curva de sobrevida de Kaplan-Meier, modificada del articulo de Hemmelgarn BR, donde se compara la sobrevida de los pacientes con insuficiencia renal que asistieron a la clinica de atención multidisciplinaria con el grupo de seguimiento estándar. ${ }^{2}$

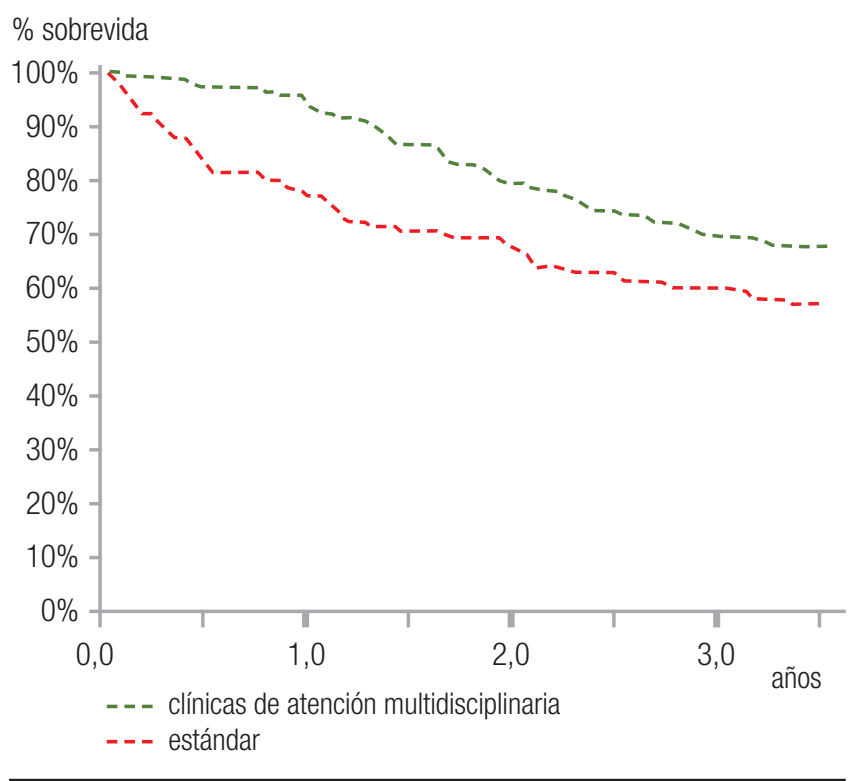


Existen dos formas de prevenir o corregir el sesgo de inmortalidad. Una es en el momento del diseño del estudio, y consiste en el "matcheo" en la selección de los sujetos. ${ }^{3}$ Siguiendo con el ejemplo, se agrega un criterio extra en la selección de sujetos en el grupo control o estándar: deben estar vivos en el momento que se le seleccionan sujetos que participan en la clínica de atención multidisciplinaria. Es decir, la cohorte empieza a correr desde que entran los sujetos a la clínica de atención multidisciplinaria y no cuando se obtiene la muestra de creatinina sérica. La otra solución es, al momento del análisis, utilizar covariables dependientes del tiempo. ${ }^{4}$ Una covariable dependiente del tiempo es un predictor cuyo valor puede cambiar con el tiempo. Por ejemplo, un paciente de una clínica de atención multidisciplinaria se consideraría no expuesto desde la fecha de ingreso al estudio hasta que visite la clínica de atención multidisciplinaria y esté expuesto desde ese punto en adelante. Muchos paquetes de software estadístico pueden incorporar covariables dependientes del tiempo en el análisis de supervivencia.

\section{Aviso de derechos de autor}

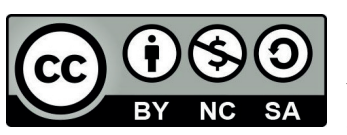

(C) 2021 Acta Gastroenterológica Latinoamericana. Este es un artículo de acceso abierto publicado bajo los términos de la Licencia Creative Commons Attribution (CC BY-NC-SA 4.0), la cual permite el uso, la distribución y la reproducción de forma no comercial, siempre que se cite al autor y la fuente original.
Cite este artículo como: Pérez de Arenaza D. Sesgo de inmortalidad en estudios observacionales. Acta Gastroenterol Latinoam. 2021;51(2):125-7. https://doi.org/10.52787/ ajuj5684

\section{Referencias}

1. Shariff SZ, Cuerden MS, Jain AK, Garg AX. The Secret of Immortal Time Bias in Epidemiologic Studies. J Am Soc Nephrol. 2008;19:841-3.

2. Hemmelgarn BR, Manns BJ, Zhang J, Tonelli M, Klarenbach S, Walsh M, Culleton BF. Association between multidisciplinary care and sur- vival for elderly patients with chronic kidney disease. J Am Soc Neph. 2007;18:993-9.

3. Rothman KJ, Greenland S. Modern Epidemiology, Philadelphia, PA, Lippincott-Raven, 1998: segunda edición.

4. Van Walraven C, Davis D, Forster AJ, Wells GA. Time-dependent bias was common in survival analyses published in leading clinical journals. J Clin Epidemiol. 2004;57:672-82. 


\title{
Immortal Time Bias in Observational Studies
}

\author{
Diego Pérez de Arenaza \\ Cardiologist. Staff Physician, Hospital Italiano de Buenos Aires. Ciudad Autónoma de Buenos Aires, Argentina. \\ Coordinator: Rodolfo Pizarro \\ Master in Clinical Effectiveness. Head of Cardiology, Hospital Italiano. Ciudad Autónoma de Buenos Aires, Argentina.
}

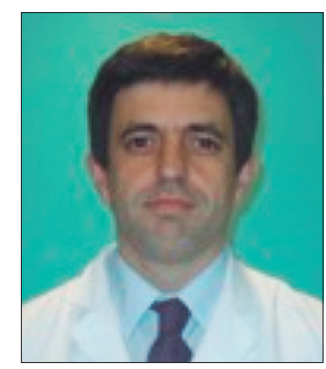

Diego Pérez de Arenaza

Acta Gastroenterol Latinoam 2021;51(2):128-130

Received: 13/05/2021 / Accepted: 14/05/2021 / Published online: 21/06/2021 / https://doi.org/10.52787/ajuj5684

Biases in the design of observational studies is one of the main sources of spurious association, in addition to chance errors or confounders. Immortal time bias is a type of bias that often occurs unnoticed by researches. This bias consists in the fact that there is a period, in the observation of the subjects, in which the event or endpoint of the study cannot occur. This is particularly important when comparing the incidence of an event between two groups: one with an exposure variable and others without it. Immortal time bias often occurs when, in the exposed group, there is a follow-up period between study entry and the determination of the exposure variable, a period in which the event or endpoint does not occur, by definition, resulting in a lower incidence of the event in the exposed group compared to the unexposed group (Figure 1). This difference in incidence is not real, but is biased by the study design that causes the immor-

Correspondence: Aníbal Arias

Email:anibal.arias@hospitalitaliano.org.ar tal time bias, where subjects are protected for a period of time from developing the event in the exposed group. This situation occurs when cohort entry occurs occurs before the determination of the exposure variable. Thus, we call immortality time bias, when there is a period of time between cohort entry and the determination of the exposure variable in which the event cannot occur by definition.

Sharif SZ clearly describes, from an article by Hemmelgarn et al., the immortal time bias. ${ }^{1,2}$ In the aforementioned article, the authors report a $50 \%$ reduction in the risk of all-cause mortality for patients who had chronic kidney disease and attended multidisciplinary care clinics compared to those who had received usual care. ${ }^{2}$ Mortality curves diverge rapidly between the group attending multidisciplinary care clinics compared to standard treatment. There is no biological plausibility in the fact that attending a multidisciplinary care clinic will result in an immediate and marked reduction in mortality. The reduction in mortality could occur over time (months or years), if patients evaluated in the multidisciplinary care clinic are accompanied by a more complete treatment and more complete treatment, with evidence-based and proven efficacy and/or associated with a better adherence to the interventions performed. The immediate reduction observed can only be explained by the immortal time bias. The Hemmelgarn's study was to examine the association between multidisciplinary care clinic and survival. It consisted of a retropective cohort of 187 clinical patients, who were exposed to a multidisciplinary care clinic, that were matched with 187 clinical control 
Figure 1. Cohort study graph plotting the exposed and unexposed groups. The period between study entry and the determination of the exposure variable corresponds to the immortal period (event-free)

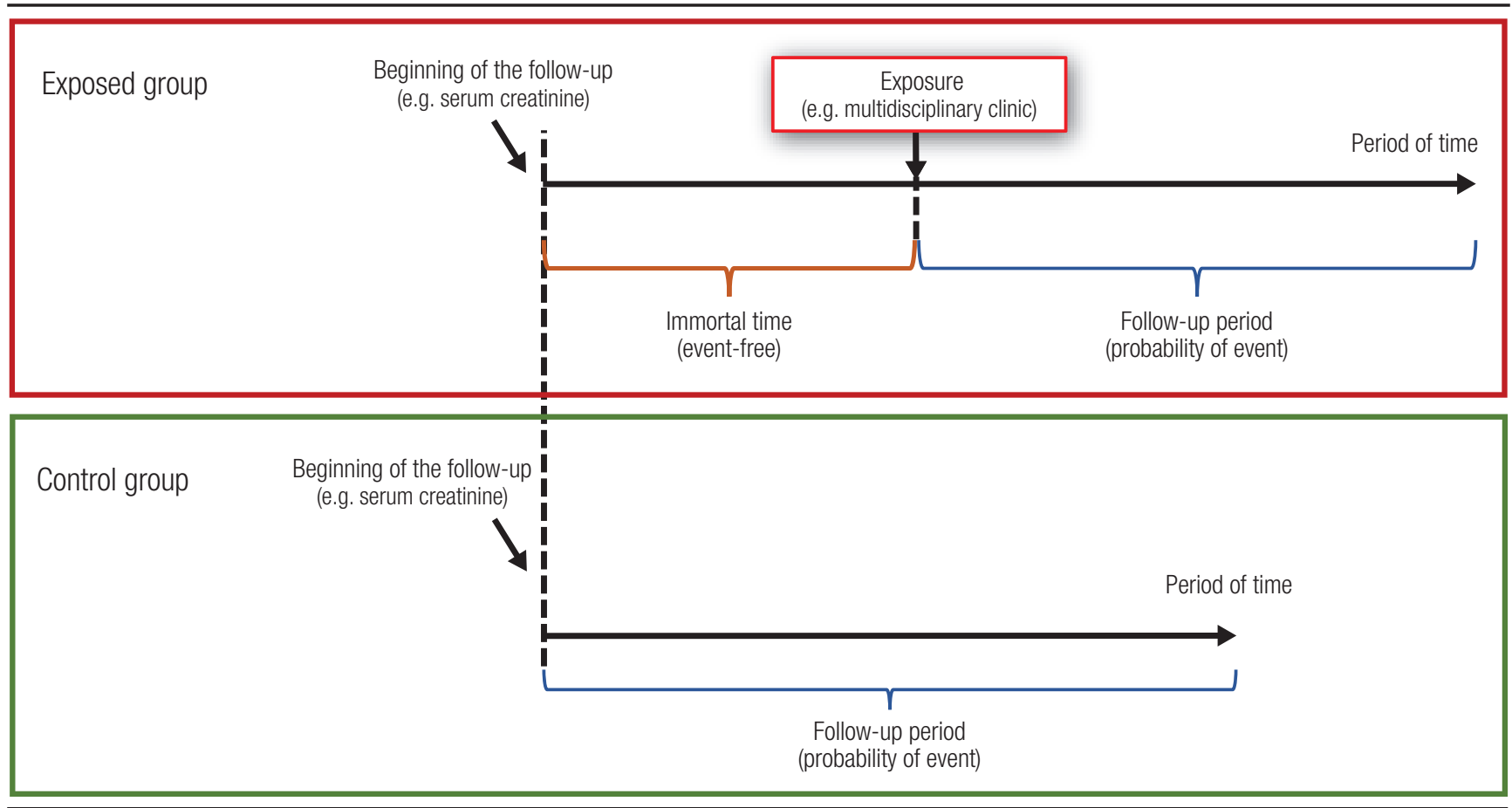

patients who were not part of a multidisciplinary care clinic (standard care). Control subjects were chosen on the basis of the propensity to match, so that individuals, in the control group, were similarly likely to be referred to a multidisciplinary care clinic as those in the multidisciplinary care clinic group. All patients were required to have an outpatient serum creatinine test performed between July 1 and December 31, 2001. The patients in the multidisciplinary care clinic group must also have attended a multidisciplinary care clinic between the July 1, 2001 and December 31, 2002. A Cox survival analysis was used between the multidisciplinary care clinic group and the standard group. Survival time was measured from the date of each patient's serum creatinine test. In other words, the date of each patient's serum creatinine represented the date they entered the cohort, or time 0 . The patients were followed until the end of the evaluation (December 31, 2004) or until death, whichever came first. The difference in survival between the two groups was illustrated by the Kaplan-Meier survival curves (Figure 2). In this analysis, censorship occurred only at the end of the evaluation; therefore, the curves essentially represent the proportion of patients who were still alive at each time point during follow-up. The curves diverge immediately, which underlines the immortality time bias. After a year and a half, the two curves have a similar slope. Much of the early beneficial effect observed may be due to immortal time bias.

Figure 2. Kaplan-Meier survival curve, modified from the article of Hemmelgarn $B R$, which compares the survival of patients with renal failure who attended the multidisciplinary care clinic with the standard follow-up group ${ }^{2}$

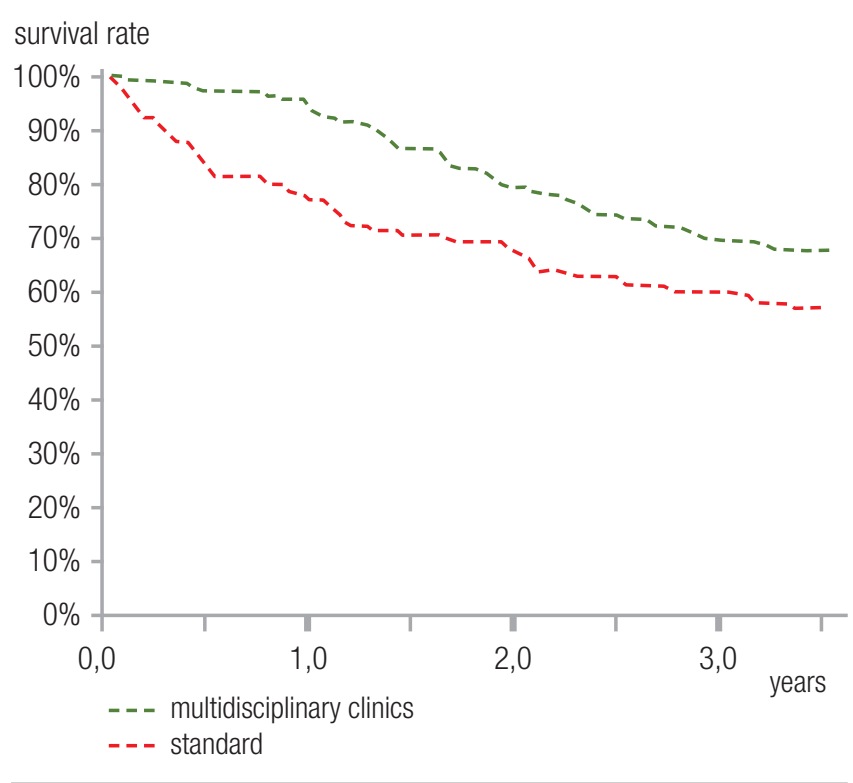


There are two ways to prevent or correct the immortal time bias. One is at the time of the study design, which consists of "matching" in the selection of the subjects. ${ }^{3}$ Continuing with the example, an extra criterion is added in the selection of subjects in the control or standard group: they must be alive at the time they are selected subjects participating in the multidisciplinary care clinic. That is, the cohort begins to run as soon as the subjects enter the multidisciplinary care clinic and not when the serum creatinine sample is obtained. The other solution is to use time-dependent covariates, at the time of analysis. ${ }^{4} \mathrm{~A}$ time-dependent covariate is a predictor whose value can change over time. For example, a patient, in a multidisciplinary care clinic, would be considered unexposed from the date of study entry until they visit the multidisciplinary care clinic and are exposed from that point forward. Many statistical software packages can incorporate time-dependent covariates in survival analysis.

\section{Copyright}

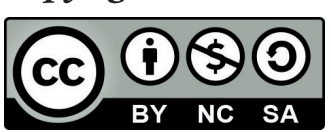

(C) 2021 Acta Gastroenterológica latinoamericana. This is an openaccess article released under the terms of the Creative Commons Attribution (CC BY-NC$S A$ 4.0) license, which allows non-commercial use, distribution, and reproduction provided the original author and source are acknowledged.
Cite this article as: Pérez de Arenaza D. Immortal Time Bias in Observational Studies. Acta Gastroenterol Latinoam. 2021;51(2):128-30. https://doi.org/10.52787/ajuj5684

\section{References}

1. Shariff SZ, Cuerden MS, Jain AK, Garg AX. The Secret of Immortal Time Bias in Epidemiologic Studies. J Am Soc Nephrol. 2008; 19:841-3.

2. Hemmelgarn BR, Manns BJ, Zhang J, Tonelli M, Klarenbach S, Walsh M, Culleton BF. Association between multidisciplinary care and sur-vival for elderly patients with chronic kidney disease. J Am Soc Neph. 2007; 18:993-9.

3. Rothman KJ, Greenland S. Modern Epidemiology, Philadelphia, PA, Lippincott-Raven, 1998: second edition.

4. van Walraven C, Davis D, Forster AJ, Wells GA. Time-dependent bias was common in survival analyses published in leading clinical journals. J Clin Epidemiol. 2004; 57:672-82. 